特集 : 転換点としてのコロナ危機

\title{
感染症対策「日本モデル」を検証する その隠された恣意性
}

田中 重人 (東北大学)

\section{要約}

「日本モデル」とは、新型コロナウイルス感染症対策専門家会議の 2020 年 4 月 1 日「新型 コロナウイルス感染症対策の状況分析・提言」(第 2 回)に出現した用語である。感染者の うちごく少数がいわゆる「3 密」の状況で大量の 2 次感染を起こすという想定に基づき、 「市民の行動変容とクラスターの早期発見・早期対応」によって感染拡大を防ぐことに力 点を置く、日本政府の取組を指す。本稿では、この想定の元となった 2020 年 2 月 26 日ま での感染状況の分析結果と、専門家がそれを改変して説明に使用してきたグラフを検討し、 恣意的な仮定に基づいた解釈がおこなわれていたこと、別の仮定を置けば日本モデルは支 持できなくなることをあきらかにする。さらに、新型コロナウイルス感染症に関してはほ かにも疑わしいデータが政策判断に使われてきたことを指摘し、第三者による批判・検証 の可能な情報が公開されるべきであることを主張する。

\section{目次}

1. 新型コロナウイルス感染症対策の「日本モデル」とは

2. 脚色された図と知見

3. 暗数の補いかたの特性

4. 何が問題か

図

図 1:「新型コロナクラスター対策専門家」が解説動画で使ったグラフ (https://twitter.com/ClusterJapan/status/1246269915314577408 に加筆)

図 2: 厚生労働省「クラスター対策班」メンバーによる論文のグラフ (doi:10.1101/2020.02.28.20029272より複製)

図 3: 平均ひとりの二次感染者を見落としていたと仮定して補正したグラフ (https://remcat.hatenadiary.jp/entry/20200408/making より作成) 


\section{文献}

新型コロナウイルス感染症対策専門家会議「新型コロナウイルス感染症対策の状沉分析・提言」(2020 年 4 月 1 日) (https://www.mhlw.go.jp/content/10900000/000617992.pdf)

高橋直純「入院は重症者優先、「変更検討を進めるべき」、専門家会議：日本型感染症対策を模索、感染未 確認地域で活動再開を推奨」m3.com 医療維新（2020 年 3 月 20 日）

(https://www.m3.com/open/iryoIshin/article/742303/)

千葉雄登「波紋呼んだ「対策ゼロなら 40 万人死亡」のデータ：いま必要なコミュニケーションは単なる「情 報提供」ではない」BuzzFeed News （2020 年 4 月 24 日）(https://www.buzzfeed.com/jp/yutochiba/riskcommunication-cluster-japan)

首相官邸メールマガジン 2020 年 3 月 23 日版 (https://www.kantei.go.jp/jp/mail/back_number/archive/2020/back_number20200323.html)

新型コロナクラスター対策専門家 @ ClusterJapanによるツイート (2020年 4 月 11 日)

(https://twitter.com/ClusterJapan/status/1248884086581514242)

@ yoh_tanimotoによるツイート (2020 年 4 月 6 日) (https://twitter.com/yoh_tanimoto/status/1246844625933012992) 厚生労働省「新型コロナウイルスに関するQ＆A」

(http://web.archive.org/web/20200229174116/https://www.mhlw.go.jp/stf/seisakunitsuite/bunya/kenkou_iryou/deng ue_fever_qa_00001.html)

川端裕人「新型コロナの広がり方 : 再生産数と「密」という大きな発見」（研究室特別編 : 新型コロナ、本 当のこと 神戸大学 中澤港) Webナショジオ（2020 年 5 月 16 日）

(https://natgeo.nikkeibp.co.jp/atcl/web/19/050800015/051200006/)

@ lematin によるツイート (2020 年 3 月 20 日) (https://twitter.com/lematin/status/1240865468904136705)

@kenmo_economicsによるツイート (2020 年 5 月 3 日)

(https://twitter.com/kenmo_economics/status/1256747964841648128)

牧野淳一郎「3.11 以後の科学リテラシー第 90 回」『科学』 2020 年 6 月号

厚生労働省コロナ対策本部クラスター対策班「2020 年 5 月 1 日の専門家会議での報告内容の補足」

(https://github.com/contactmodel/20200501/blob/master/0501_public.pdf)

新型コロナクラスター対策専門家@ClusterJapanによるツイート (2020年 4 月 4 日)

(https://twitter.com/ClusterJapan/status/1246269915314577408)

Nishiura H, Oshitani H, Kobayashi T, Saito T, Sunagawa T, Matsui T, Wakita T, MHLW COVID-19 Response Team, Suzuki M. "Closed environments facilitate secondary transmission of coronavirus disease 2019 (COVID-19)". medRxiv (doi:10.1101/2020.02.28.20029272) (2020-04-16)

田中重人「「8 割は人にうつさない」は嘘? (3): 数字の盛りかた指南」 remcat: 研究資料集 (2020 年 4 月 8 日) (https://remcat.hatenadiary.jp/entry/20200408/making)

\section{謝辞}

本稿の執筆にあたり、ツイッター等で寄せられた情報を参考にしました。また多くのかたからコメントをい ただき、草稿を改善しました。いちいち記しておりませんが、この場を借りて御礼申し上げます。 